
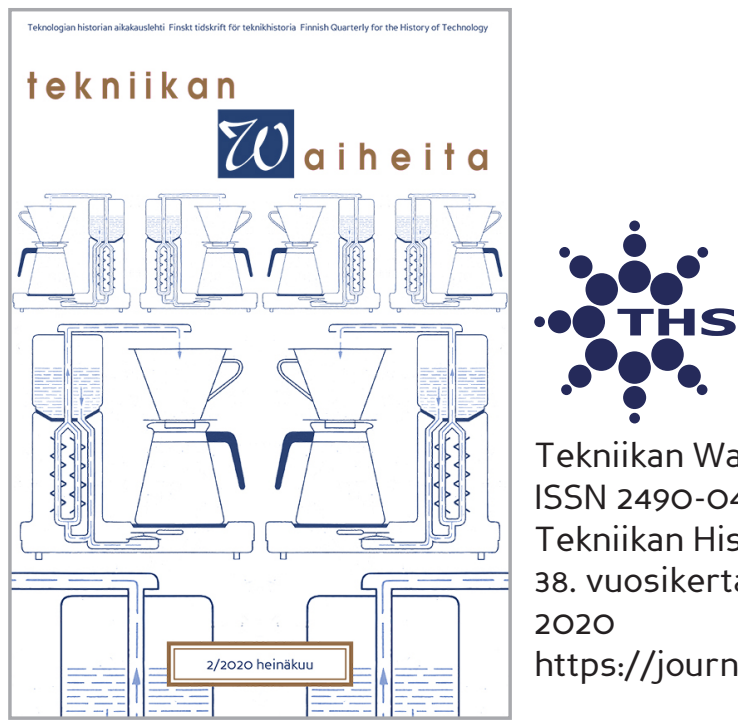

Tekniikan Waiheita

ISSN 2490-0443

Tekniikan Historian Seura ry.

38. vuosikerta:2

2020

https://journal.fi/tekniikanwaiheita

\title{
Punainen V-kirjain varren päässä - sammutusvedenottopaikkojen merkit Suomessa
}

Vesa Linja-aho

To cite this article: Vesa Linja-aho, "Punainen V-kirjain varren päässä - sammutusvedenottopaikkojen merkit Suomessa" Tekniikan Waiheita 38, no. 2 (2020): 22-33. https:/ /dx.doi. org/10.33355/tw.96986

To link to this article: https://dx.doi.org/10.33355/tw.96986 


\section{Punainen V-kirjain varren päässä - sammutusvedenottopaikkojen merkit Suomessa}

Vesa Linja-aho'

Sisäasiainministeriö määräsi vuonna 1943 palokunnan sammutusvedenottopaikat merkittäväksi noin 1,5 metrin korkeuteen sijoitetulla punaisella V-kirjaimella. Sammutusvedenjakeluverkoston rakentaminen perustui vuoden 1933 palosääntöön, jossa oli määräys riittävästä sammutusveden saannista. Vesijohtoon liitetyt palopostit, jotka on vuodesta 1961 merkitty sinireunaisella palopostin avainta kuvaavalla pienellä taululla, ovat syrjäyttäneet erilliset vedenottopaikat V-merkkeineen, mutta V-opasteita löytyy edelleen teiden varsilta ympäri Suomea.

Arkiympäristössä esiintyy usein esineitä, joihon joko ei kiinnitä huomiota tai ne ovat niin itsestäänselvyyksiä, että niitä ei käsitellä erikseen kirjallisissa aikalaislähteissä. Vanhassa valokuvassa voi näkyä esine tai rakennelma, jonka alkuperäinen tarkoitus on kadonnut kollektiivisesta muistista. Esimerkiksi liikennevalopylväässä näkyvä mikroaaltotutka voi olla sadan vuoden päästä kaupunkikuvan esine, jonka merkitys selviää vain aikalaisblogikirjoituksesta ${ }^{2}$ tai liikennevalovalmistajan piirustuksista, mikäli ne on arkistoitu.

Suomessa teiden varsilla näkyy siellä täällä noin ihmisen pituisia tolppia, joiden merkitystä ihmetellään silloin tällöin sosiaalisessa mediassa. Esimerkiksi vuonna 2009 vapaaehtoisvoimin ylläpidettävän karttapalvelu OpenStreetMapin foorumilla kummasteltiin maaseudulla joskus risteyksissä näkyviä liikennemerkkejä, joissa on punainen V-kirjaimen muotoinen kuvio. Vastaaja arveli, että kyseessä on palokunnan vedenottopaikka ja kertoi olleensa joskus rakentamassa sellaista. ${ }^{3}$ Suomi24-palstalla toistui sama pari vuotta myöhemmin, lukijaa ihmetytti outo liikennemerkki: ${ }^{4}$

Elikekä punainen V :een näköinen merk.ki ilman mitään taustaa eikä ylä reunaa. Pelkekä V tolpan varassa. Näitä näkee sillöin tällöin maaseudulla.

Toinen nimimerkki tiesi vastata, että

Kyseessä ei ole liikennemerkki, vaan vedenottopaikan merk.ki, lähinnä palolaitoksen tarpeisïn. Samoin taajamissa törmäa "T"-merkkiïn, joissa on erilaisia numeroita merkkaamassa palopostin sijaintia merkekiin näbden.

\footnotetext{
${ }^{1}$ Kirjoittaja on sähkötekniikan diplomi-insinööri ja tekniikan historian harrastaja.

2 Järvinen 2010.

${ }^{3}$ OpenStreetMap Forum 2009, forum.openstreetmap.org.

${ }^{4}$ Suomi24 2011, www.suomi24.fi.
} 


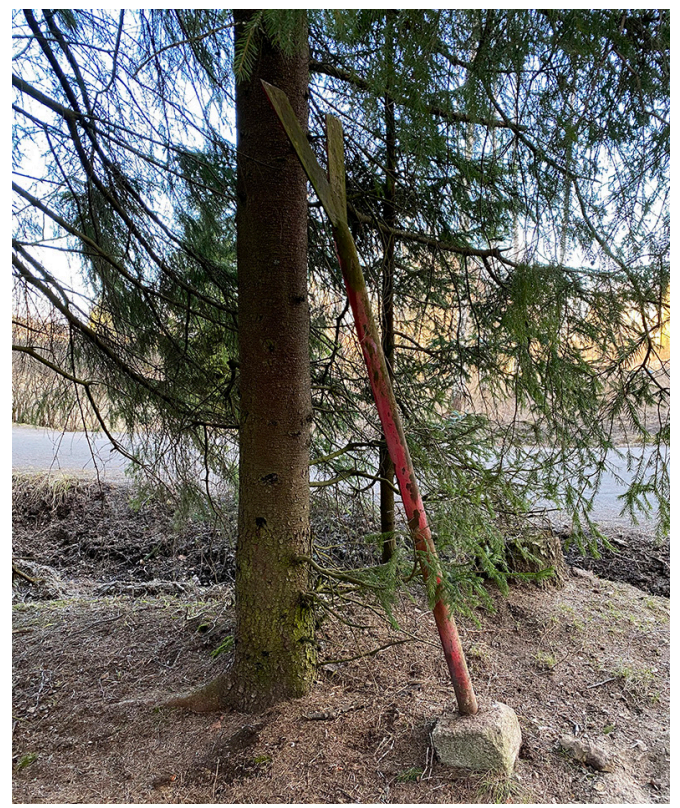

Kuva 1. Metallinen Sammutusvedenottopaikan merkki Espoon Rastaalassa huhtikuussa 2020. Vesa Linja-aho.

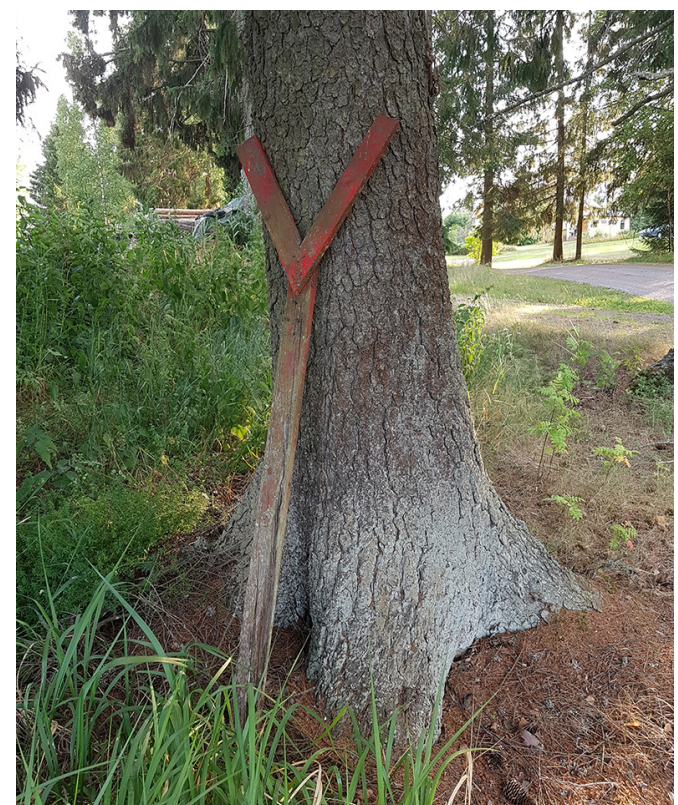

Kuva 2. Puinen sammutusvedenottopaikan merkki Ypäjällä 2019. Wikimedia Commons, käyttäjä Urjanhai, julkaistu CC BY-SA 4.0 -lisenssillä. https://commons.wikimedia.org/w/index. php?curid $=81059951$

V-merkit ovat esimerkki rakennetun arkiympäristön kulttuuriperinnöstä, joiden merkitys on ollut aikalaisille itsestään selvä ja pikkuhiljaa häviää kollektiivisesta muistista. Merkit ovat palokunnan sammutusvedenottopaikkoja, joiden ulkoasusta säädettiin sisäministeriön päätöksessä vuonna 1943. Päätöksen ${ }^{5}$ mukaan

\section{Vedenottopaikan merkkei on punainen $V$-kirjain. Ellei punainen väri taustan vuoksi ole helposti havaittava, on merkin väri valkoinen. Merkin kylkien sisäpituus on 40 ja leveys 7.5 senttimetriä. Jos merkeki on havaittava kaukaa, on se tehtävä vastaavasti suuremmaksi. Mikäli näkyväisyys ei toisin vaadi, maalataan tai asetetaan merkki siten, että sen alareuna on $n .1 .6$ metrin kor- keudella.}

Päätöksessä säädetään myös vedenottopaikan kapasiteetin merkitsemisestä (minuuttilitrakapasiteetti merkitään V:n alle valkoisella kilvellä) ja suuntanuolen käytöstä (lisäkilpi tai nuoli on asetettava niin, että kärki osoittaa vedenottopaikan suunnan). Jos vedenottopaikka soveltuu sekä auto- että moottoriruiskulle, on kilven keskelle maalattava A, ja jos vedenottopaikalle päästään ainoastaan moottoriruiskulla, M. Kuvissa 1 ja 2 on esimerkki nykypäivään asti säilyneestä metallisesta ja puisesta vedenottopaikan merkistä. Kuvassa 3 näkyy palokaivo merkkeineen 1940-luvulla.

\footnotetext{
${ }^{5}$ Sisäasiainministeriön päätös sammutusvedenottopaikkojen merkitsemisestä 1031/1943.
} 


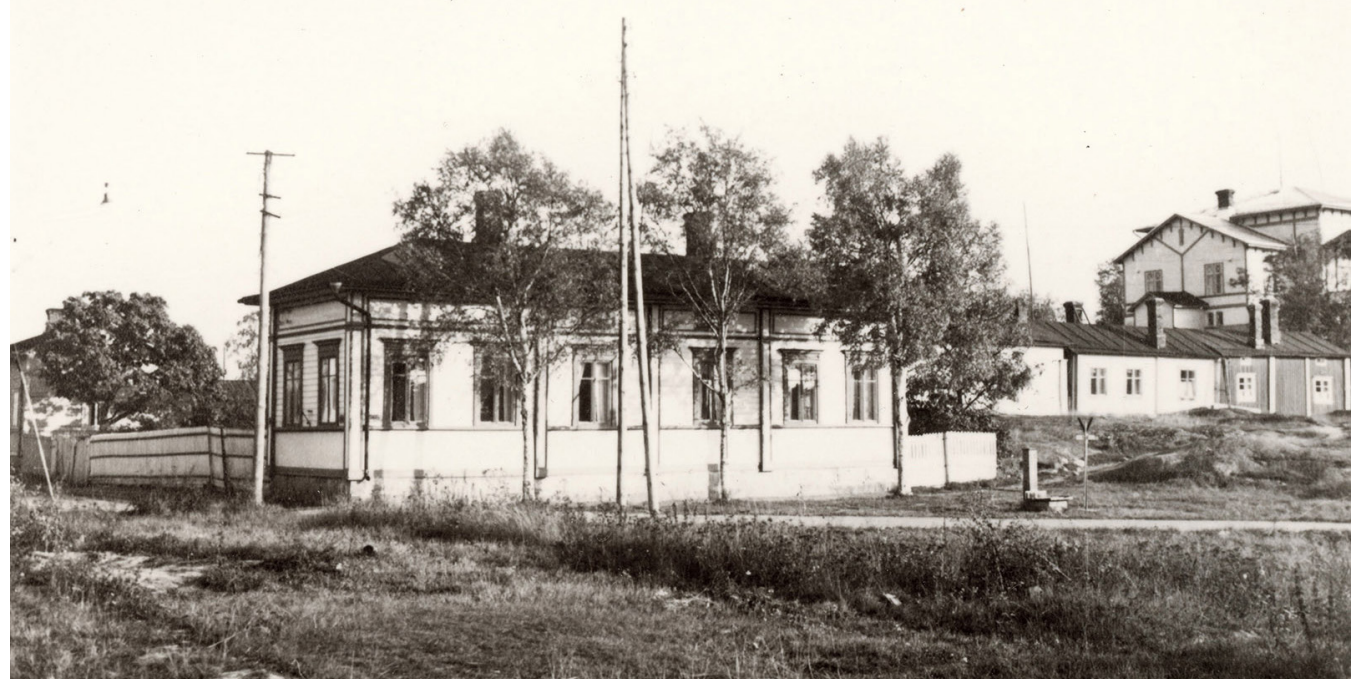

Kuva 3. Katunäkymä Uudestakaupungista 1940-luvulta. Talon edessä oikealla näkyy palokaivo V-merkkeineen. Uudenkaupungin museon valokuvakokoelma. Julkaistu CC BY ND 4.0 -lisenssillä. https://www.finna.fi/Record/musketti_tmk.M20:9058:

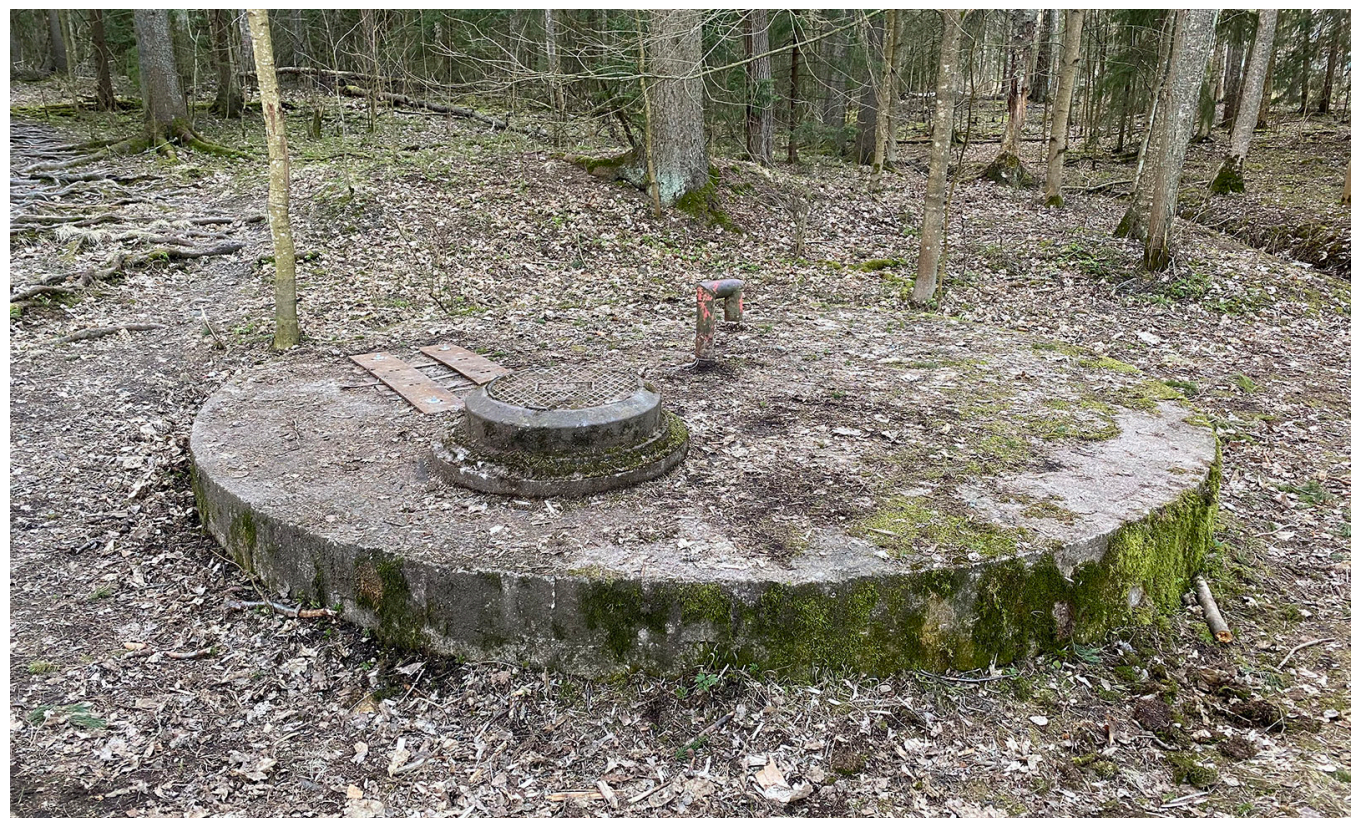

Kuva 4. Palokaivo Espoon Rastaalassa. 
Kuvan 1 merkin osoittama palokaivo (kuva 4) sijaitsee noin 15 metrin päässä merkistä ja tiestä. Palomestari Tero Kähkönen Länsi-Uudenmaan pelastuslaitokselta kertoo, että he eivät enää käytä tätä eikä muitakaan palokaivoja, eikä niitä ole merkitty sammutusveden hankintaan tarkoitettuihin karttoihin. Sammuttaminen tapahtuu vesijohtovedellä tai luonnonvedellä, joko ajettuna tai suoraan letkuilla kuljetettuna. ${ }^{6}$ Alueella vuodesta 1936 toimineen Pitkäjärven VPK:n rahastonhoitaja Tarja Gustafsson kertoo, että paikka on tuttu heidän vanhemmille jäsenilleen ja palokaivo on ollut olemassa ainakin jo 1950-luvulla. ${ }^{7}$ Vapaapalokunnan historiikissa palokaivo mainitaan yhtenä alueen palokaivoista "Rastaalan palokaivo Rastaalan koulun alapuolella notkossa lähellä entistä kauppaa". ${ }^{8}$ Palokaivossa lienee ollut vettä noin 1,5-2 metriä ja sen kannen halkaisija on ollut noin kolme metriä. ${ }^{9}$ Tuntomerkit ja sijainti täsmäävät paikalla vieläkin olevaan kaivoon. HSY:n karttojen mukaan kaivon sijaintikohdassa ei mene vesiputkia, ${ }^{10}$ joten kaivo saa ilmeisesti vetensä viereisestä ojasta.

Vuoden 1943 sisäministeriön päätös sammutusvedenottopaikkojen merkitsemisestä on annettu samana vuonna annetun asetuksen ${ }^{11}$ nojalla. Asetus puolestaan on annettu vuoden 1933 palolain nojalla. ${ }^{12}$ Palolain ja sen nojalla 1933 annetun palosäännön mukaan asemakaavaan tai rakennussuunnitelmaan otetuilla tai taajaan asutuilla alueilla oli järjestettävä vedenottopaikkoja siten, ettei alueen eri osissa sattuvissa tulipaloissa tarvitse, pakottavia poikkeustapauksia lukuun ottamatta, selvittää pitempää kuin 300 metrin letkujohtoa. ${ }^{13}$ Maalaiskunnissa edellytettiin järjestettäväksi pieniä vesivarastoja, jos vedensaantimahdollisuudet olivat huonot. ${ }^{14}$ Tätä taustaa vasten on vedenottopaikkojen ja siten niiden merkkien runsas määrä on ymmärrettävä.

Palolaki uudistettiin vuonna 1960. Palosäännön vuonna 1961 kumonnut uuden palolain nojalla annettu paloasetus sisältää olennaisilta osiltaan identtisen määräyksen sammutusveden saannista:

Sammutusveden saanti on järjestettävä niin, että se paikalliset olosubteet huomioon ottaen on riittävä. Sammutusvedenottopaikat on pidettävä mahdollisunksien mukaan kunnossa myös talvella.

Kaupungin ja kauppalan asemakaava-alueella sekë olosubteiden niin vaatiessa 21 J:n 2 momentissa mainitulla alueella on järjestettävä sammutusvedenottopaikekoja siten, että alueen eri osissa on vettä saatavissa enintään 300 metrin etäisyydeltä, jollei lääninhallitus erityisestä syystä myönnä tästä poikkeusta.

\footnotetext{
${ }^{6}$ Tero Kähkösen sähköposti 16.4.2020.

${ }^{7}$ Tarja Gustafssonin sähköposti 17.4.2020.

${ }^{8}$ Pohjakallio 2006, 122.

${ }^{9}$ Pohjakallio 2006, 124.

${ }^{10}$ HSY:n asiakaspalvelun sähköposti 16.4.2020.

${ }^{11}$ Asetus sammutusvedenottopaikkojen merkitsemisestä 1943.

12 Palolaki 1933.

13 Haiko 2014, 35.

14 Haiko 2014, 35.
} 

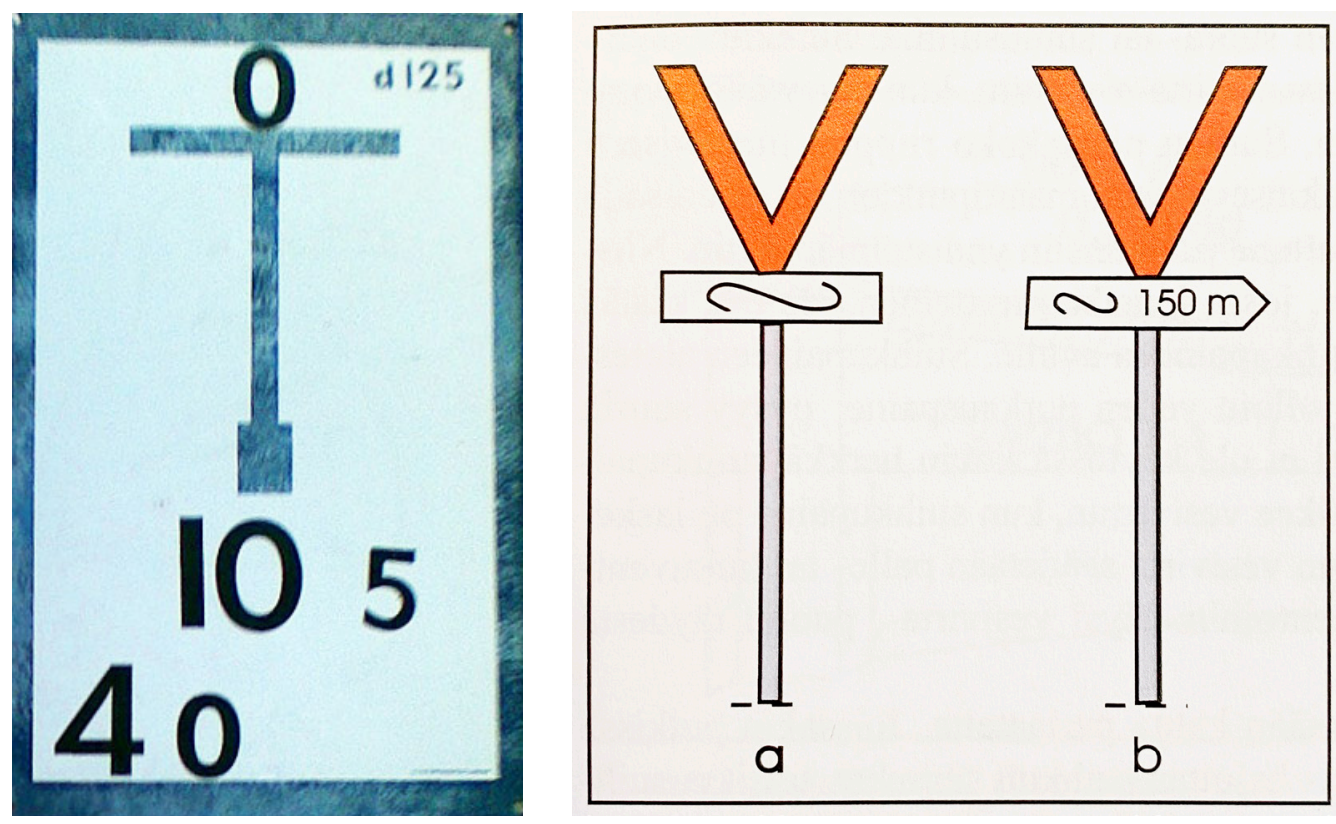

Kuva 5 (vas.). Sisäasiainministeriön päätöksen (212/1964) mukainen palopostitaulu. Palopostin etäisyys kilvestä on 10,5 metriä kohtisuoraan ja 4,0 metriä tästä vasemmalle. Vesijohtoputken läpimitta on 125 millimetriä. Merkintä O tarkoittaa oikeankätistä aukeamissuuntaa. OpenStreetMap-wiki, käyttäjä Alv, julkaistu CC BY-SA 2.0 -lisenssillä. https://wiki.openstreetmap.org/ wiki/File:Markerhydrant.jpg

Kuva 6 (oik.). Luonnonvedenottopaikan merkintä. Aaltoviiva tarkoittaa rajatonta vesivirtaa ja suuntanuoli ilmaisee vedenottopaikan sijainnin. Kuva oppikirjasta Palofysiikka's.

Vuoden 1961 asetuksen nojalla annettu uusi päätös vedenottopaikkojen merkitsemisestä (212/1964) on palokaivojen osalta samanlainen, mutta palopostien merkitsemisestä oli uusi määräys:

Maanalaisen palopostin merkekinä käytetään $20 \mathrm{~cm} \times 30 \mathrm{~cm}$ suuruista kilpeä, jossa on valkoisella pobjalla sininen tyylitelty $13 \mathrm{~cm}$ korkea ja $10 \mathrm{~cm}$ pitkeällä kädensijalla varustettu alapäästään $25 \mathrm{~mm}$ pituudelta $20 \mathrm{~mm}$ ja muntoin $10 \mathrm{~mm}$ leveä palopostin avain. Avaimen alle merkitään tarvittaessa mustilla numeroilla palopostin kohtisuora etäisyys kilvestä $10 \mathrm{~cm}$ tarkekundella ja tämän alapuolella jompaan kumpaan reunaan luku, joka ilmoittaa kyseessä olevaan suuntaan palopostin etäisyyden edellä mainitusta kohtisuorasta linjasta. Metrejä ilmaiseva luku merkitään $40 \mathrm{~mm}$ ja metrin kymmenesosat $30 \mathrm{~mm}$ suuruisilla numeroilla. Kilven yläreunaan voidaan merkitä vasemmalle palopostin järjestysnumero ja oikealle vesijobtoputken läpimitta milli-metreinä. Kilpeä ympäröi 15 mm leveä sininen reunus.

\footnotetext{
${ }^{15}$ Hyttinen ym. 2018, 257.
} 
Vuoden 1943 päätöksessä säädettiin paloposteista ainoastaan, että maanalaisten palopostien merk.kinä voidaan edelleen käyttää aikaisemmin käytännössä olleita mittakilpiä.

Palokaivoja käytettiin erityisesti maaseudulla ja pienemmissä kaupungeissa. Esimerkiksi Helsingissä oli vuoden 1933 lopussa vain kolme palokaivoa, kun vesijohtoon kytkettyjä paloposteja oli peräti $1372 .{ }^{16}$ Espoossa palokaivoja rakennettiin työllisyystöinä 1930-luvulta aina 1950-luvulle asti. ${ }^{17}$ Palokaivoja rakennettiin myös talkoilla. Kaivo ei välttämättä ollut kaivo kaivonrenkaineen ja -kansineen, vaan saattoi olla vain maahan kaivettu kuoppa, joka täyttyi vedellä. ${ }^{18}$

Voimassa olevassa pelastuslaissa ei enää puhuta metrimääristä, vaan pelastuslaitokselta vaaditaan sammutusvesisuunnitelma, ja kunnan tulee huolehtia alueellaan sammutusveden hankinnasta pelastuslaitoksen tarpeisiin sammutusvesisuunnitelmassa määritellyllä tavalla. ${ }^{19}$ Vedenottopaikat on merkitty palopostikarttoihin, ja löytyvät yleensä helposti. ${ }^{20}$ Palopostitaulut ovat edelleen käytössä, ja ovat lähes identtisiä vuoden 1964 päätöksessä kuvatun kanssa. Palopostin avain on musta ja sen päälle merkitään venttiilin avautumissuunta $\mathrm{O}$ - tai V-kirjaimella. ${ }^{21}$ Kuvassa 5 on esimerkki palopostitaulusta.

Vaikka pelastuslain nojalla ei ole enää annettu asetuksia tai määräyksiä vedenottopaikkojen merkitsemisestä, vuoden 1964 päätöstä vedenottopaikkojen merkitsemisestä ei ole Finlex-tietopalvelun viitetietojen mukaan myöskään kumottu. Määräyksen mukainen luonnonvedenottopaikan merkki kuvataan vielä pelastusalan oppikirjassa (kuva 6).

Yksi oppikirjan kirjoittajista, Pelastusopiston vanhempi opettaja Timo Väisänen kertoo, että luonnonvedenottopaikkoja pidetään enää yllä lähinnä turvetuotantoalueilla, jossa ne tarkastetaan palotarkastuksien yhteydessä. Muuten niistä ollaan luopumassa ja pitkälti myös luovuttu. ${ }^{22}$

\section{Pohdinta}

Monen arkiympäristössä näkyvän esineen tarkoituksen selvittäminen voi olla hankalaa aikalaisellekin, jos ei tiedä esineen nimeä, jolla voi hakea lisätietoa. Esimerkiksi maaseudulla päätieltä haarautuvien teiden päässä on vieläkin puupylväitä, joiden päässä on mustia numeroita ja kirjaimia. ${ }^{23}$ Nämä ovat suurjännitelinjojen johto-opasteita (kuva 7), jotka nykyaikaiset GPS-karttajärjestelmät ovat tehneet käytännössä tarpeettomiksi.

Voimalinjassa roikkuva "mehiläispesä" taas on nimeltään kantoaaltokuristin. ${ }^{24}$ Metsässä vastaan tulevat putkenpäät, joiden päässä on lukollinen luukku, taas ovat pohjaveden havaintoputkia. $^{25}$

Mikäli artefakteja ei ole dokumentoitu julkaistuissa teoksissa, kuten asia voi olla esimerkiksi kriittisen infrastruktuurin kanssa, tieto jää elämään ainoastaan alalla työskennelleiden

\footnotetext{
${ }^{16}$ Kertomus Helsingin kaupungin kunnallishallinnosta 1933, 56.

17 Juuti ja Rajala 2007, 32-36.

18 Verainen 2014, www.wirmo-seura.fi.

19 Pelastuslaki 379/2011 30 §.

${ }^{20}$ Yle 15.7.2010.

21 Jalomäki 2018.

22 Timo Väisäsen sähköposti 27.4.2020.

${ }^{23}$ Esim. Järvinen 2013.

${ }^{24}$ Esim. Koivunen 2009.

${ }^{25}$ Suomen ympäristökeskus 2017.
} 


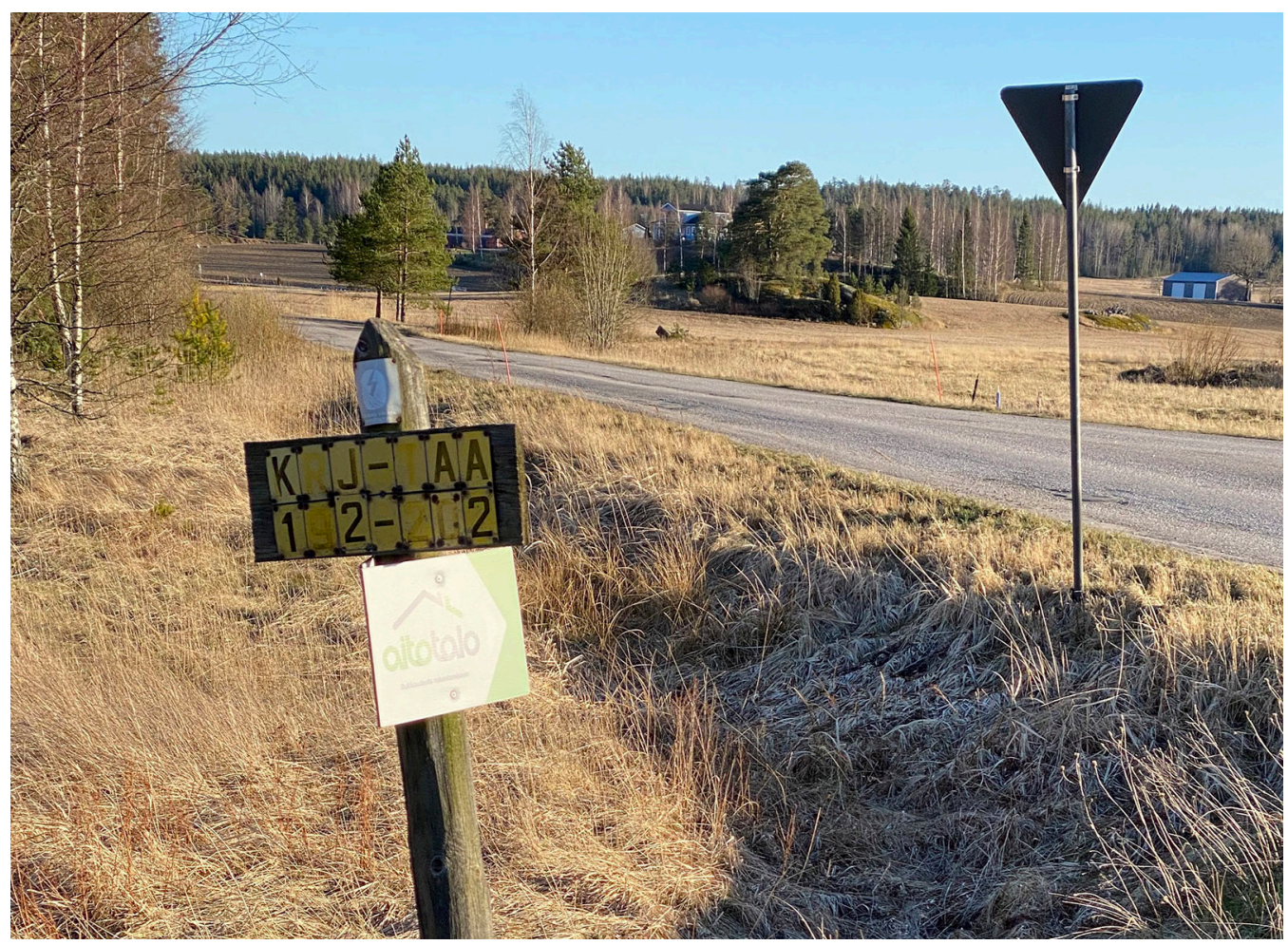

Kuva 7. Imatran Voiman aikainen johto-opaste Kemiössä kuvattuna huhtikuussa 2020. Pylvään päässä näkyy haalistunut Imatran Voiman logo. Alla on sähköasemien lyhenteet ja pylväiden numerot. Kuva: Vesa Linja-aho.

muistitietona, joka leviää kuulopuheena. Tällöin tieto voi värittyä matkalla ja siihen lisätään jännitystä tuovia tarinallisia elementtejä. Esimerkiksi punaisten posti- ja lennätinlaitoksen kilvellä varustettujen metallitolppien luullaan usein olevan merkkinä nimenomaan Yhdysvaltojen ja Neuvostoliiton väliselle kuumalle linjalle, ${ }^{26}$ vaikka samoilla tolpilla merkittiin kaukoliikennekaapeleita yleisestikin. ${ }^{27}$

Puutteellinen käsittely joukkotiedotusvälineissä voi ruokkia vääriä käsityksiä. Esimerkiksi Helsingin Sanomien artikkeli28 "ruosteisista tötteröistä" talojen katolla jättää mainitsematta, että vastaavia moottorisireenejä (laitteen nimi, jota ei edes mainita koko artikkelissa) on käytössä väestöhälyttiminä vieläkin, joskin niitä on jatkuvasti korvattu kaiutinsireeneillä, jotka mahdollistavat myös puhetiedotteiden kuuluttamisen. Järjestelmä ei ole missään nimessä vanhentunut tai tarpeeton, vaan sitä käytetään yleisen vaaramerkin antamiseen ja sitä testataan kokeilumerkillä joka kuukauden ensimmäisenä arkimaanantaina. ${ }^{29}$ Yleistä vaaramerkkiä kutsuttiin ennen yleiseksi hälytysmerkiksi, ja sen aiheuttamista toimenpiteistä oli ohjeet muun muassa puhelinluetteloiden sisäkansisivulla.

\footnotetext{
${ }^{26}$ Mm. Helsingin Uutiset 26.12.2017; Uusi Lahti 5.12.2019; Yle 10.12.2019.

${ }^{27}$ Linja-aho 2017.

${ }^{28}$ Helsingin Sanomat 25.1.2020

${ }^{29}$ Sisäministeriön pelastusosasto. pelastustoimi.fi
} 
Huolimaton otsikointi tai sanavalinta voi muodostaa aivan uudestakin ilmiöstä väärän käsityksen. 2000-luvun ensimmäisellä vuosikymmenellä harrastajapiireissä yleistyivät niin sanotut fiksipyörät, joissa ei ole vapaaratasta, vaan polkimet pyörivät aina pyörän liikkuessa. Fiksipyörässä ei myöskään ole perinteistä jalkajarrua, vaan jarruttaminen tapahtuu esimerkiksi käsijarrulla tai polkemalla takaperin. Fiksipyöriä koskevassa uutisoinnissa toistunut sanavalinta "jarruttomista fiksipyöristä” ${ }^{30}$ loi väärinkäsityksen, että fiksipyörä on yhtä kuin jarruton pyörä. Helsingin Sanomien kommenttiosasto ei ole arkistoitunut, mutta muistan kun joku tuomitsi idean älyttömäksi ja visioi, milloin joku keksii tuoda markkinoille myös jarruttomia fiksiautoja. Sama ivailu löytyy myös suositun Muropaketti-keskustelufoorumin

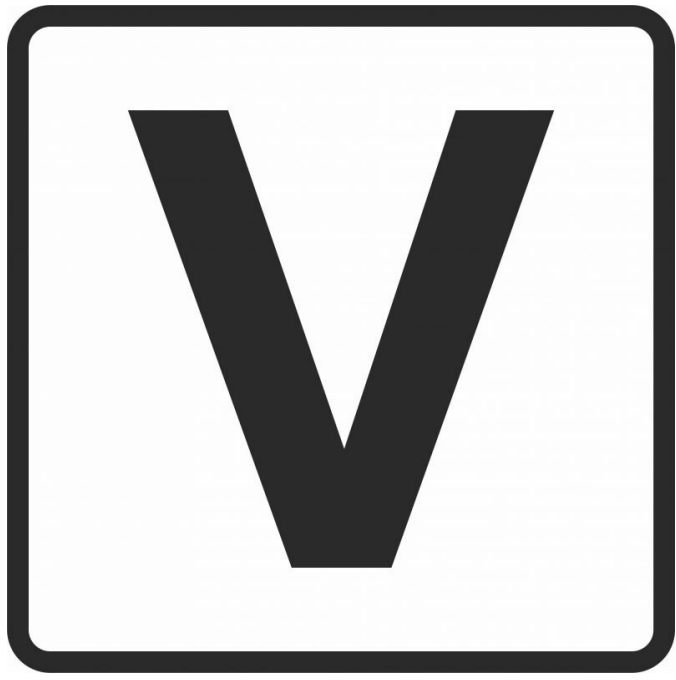

Kuva 8. V-kirjainmerkki, jota käytetään todennäköisesti vesijohtojen merkitsemiseen kaivinkoneita varten. fiksipyöräsäikeestä. ${ }^{31}$ Väärinkäsitykset herättivät sekä ärtymystä että hilpeyttä fiksipyöräharrastajien verkkokeskusteluissa. ${ }^{32}$

Aivan jokapäiväisenkin teknologian toiminta ja merkitys voi unohtua muutamassa vuosikymmenessä. Esimerkiksi lankapuhelimia on vielä käytössä, mutta lapsille ja nuorille käyttö ei ole itsestäänselvyys. Eräässä kokeilussa kahdeksasluokkalaiset tekivät kaikki saman virheen testatessaan lankapuheliminen käyttöä: numero valittiin ensin ja vasta sitten nostettiin luuri. ${ }^{33}$

Wikipedia-artikkeli palokaivoista on kirjoitettu vasta vuonna $2019,{ }^{34}$ V-kirjainten merkityksen selvittyä kirjoittajalle sattumalta. ${ }^{35}$ Alkuperäinen Wikipedia-artikkelin tieto oli epätarkkaa, koska V-kirjaimella merkittiin kaikki sammutusvedenottopaikat, ei ainoastaan palokaivoja, kuten artikkelissa alun perin väitettiin.

Oma lukunsa on tapakulttuuriin tai vakiintuneeseen käytäntöön perustuva aineeton kulttuuriperintö, josta ei välttämättä jää jäljelle auktoritatiivista kirjallista lähdettä. Esimerkkinä mainittakoon tapa, jossa yritykseen lähetetyn kirjeen saa avata kuka tahansa yrityksen edustaja, jos yrityksen nimi on kirjekuoren kannessa ennen henkilön nimeä. Jos taas henkilön nimi on ylemmällä rivillä, kirjeen saa avata vain henkilö itse, ellei toisin ole sovittu.

Aina ei merkin merkitys ole tiedossa edes sitä myyvällä taholla. Kolme merkintäkilpiä myyvää verkkokauppaa pitää valikoimissaan valkoisella pohjalla olevaa mustaa V-kirjainmerkkiä (kuva 8).

\footnotetext{
${ }^{30}$ Mm. Kaleva 8.8.2007, Helsingin Sanomat 27.7.2008, Yle Uutiset 12.5.2009

${ }^{31}$ Muropaketti 2008, murobbs.muropaketti.com.

${ }^{32}$ Moni meistä on rikollinen - jarruttomuuskeskustelu. 2008. Yksivaihde.net

33 Sihvonen 2019.

${ }^{34}$ Wikipedia 2019.

${ }^{35}$ Wikipedia 2020.
} 
Yhdessä yrityksistä muistellaan, että merkki on lisätty valikoimaan yhden asiakkaan toiveesta, ja tarve oli muistikuvan mukaan putkilinjan merkintää varten. ${ }^{36}$ Toisessa yrityksessä merkin käyttötarkoitusta ei tiedetä, ${ }^{37}$ ja kolmannesta kerrotaan, että kyseisellä V-merkillä merkitään vesijohtoja muun muassa kaivinkoneiden opastusta varten. ${ }^{38}$ Merkin menekki on yhden yrityksistä mukaan "lähes olematonta", joten merkki on todennäköisesti vain yhden tai muutaman vesilaitoksen käytössä ja sillä merkitään vesijohtoja. Esimerkiksi pääkaupunkiseudun vesihuollosta vastaavan HSY:n asiakaspalvelun mukaan merkki on heidän putkimestareilleen vieras. ${ }^{39}$

Vaikka vesijohtoverkoston laajeneminen on tehnyt palokaivot ja muut luonnonvedenottopaikat lähes tarpeettomiksi, jäävät palokaivot elämään paikannimistössä. Espoon Leppävaaran palokaivosta muistuttavat Palokaivonkuja, Palokaivonpolku ja Palokaivon koirapuisto. Espoon Friisilässä sijaitsee Palokaivonkentän leikkipaikka ja Palokaivonkäytävä. Helsingin Haagasta löytyy Palokaivon aukio. Kaiken kaikkiaan Maanmittauslaitoksen Karttapaikka-palvelun haulla Suomesta löytyy kymmenen Palokaivontietä, kaksi Palokaivonkujaa sekä yksi Palokaivo-niminen talo.

\footnotetext{
36 Jani Rämäsen sähköposti 15.4.2020.

${ }^{37}$ Kimmo Härön sähköposti 16.4.2020.

${ }^{38}$ Tiia Laukkasen sähköposti 16.4.2020.

${ }^{39}$ HSY:n asiakaspalvelun sähköposti 17.4.2020.
}

\section{Lähdeluettelo}

\section{Verkkosivut}

Helsingin Sanomat. 27.7.2008. "Poliisi tyrmää jarruttomat fiksipyörät." STT. https://web.archive.org/ web/20100601084620/http://www.hs.fi/kotimaa/artikkeli/Poliisi+tyrmää+jarruttomat+fiksipyör ät/1135238146097

Helsingin Sanomat. 25.1.2020. "Mitä ovat ruosteiset tötteröt talojen katoilla keskellä Helsinkiä? Niiden ulina oli sotavuosina merkki kuolemanvaarasta." https://www.hs.fi/kaupunki/helsinki/art-2000006384352.html

Helsingin Uutiset. 26.12.2017. "Kylmän sodan salainen kuuma linja kulki Suomen läpi - vahinkoja sattui, kun matalien rautapaalujen salaisuutta ei paljastettu." https://www.helsinginuutiset.fi/artikkeli/592149-kylman-sodan-salainen-kuuma-linja-kulki-suomen-lapi-vahinkoja-sattui-kun-matalien.

Jalomäki, Esa. 20.6.2018. Venttiiliprikkojen ja palopostitaulujen asennus. https://www.espoo.fi/download/ noname/\%7BAC32D06C-4A3E-45F9-BCF8-DDDFB1FE4A57\%7D/114161.

Järvinen, Jouko. 2013. "Imatran Voiman aikainen johto-opaste." Suuria seisovia pylväitä. https://calm.iki.fi/ tolpat/kuva/7368.

Järvinen, Petteri. 31.8.2010. "Mikä laite liikennetolpassa?" Blogikirjoitus. https://web.archive.org/ web/20111113134709/http://pjarvinen.blogspot.com/2010/08/mika-laite-liikennevalotolpassa.html.

Kaleva. 8.8.2007. " Jarruton Fix-pyörä vaatii taitavan kuskin." https://www.kaleva.fi/uutiset/kotimaa/jarruton-fix-pyora-vaatii-taitavan-kuskin/28562/

Koivunen, Jani. 2009. "110 kV linja ja kantoaaltokuristin." Suuria seisovia pylväitä. https://calm.iki.fi/tolpat/ kuva/3789.

Muropaketti. 2008. "Fiksipyörä." https://murobbs.muropaketti.com/threads/fiksipyoerae.542001/page-12

OpenStreetMap Forum. 2009. "Punaiset V-kirjaimet maaseudulla risteyksissä." https://forum.openstreetmap.org/viewtopic.php?id=4695. 
Sisäministeriön pelastusosasto. Toiminta yleisen vaaramerkin soidessa. https://www.pelastustoimi.fi/turvatietoa/toimi-oikein-hatatilanteessa/toiminta-yleisen-vaaramerkin-soidessa

Suomi24. 2011. "Vanha liikennemerkki 'V'." https://keskustelu.suomi24.fi/t/10260591/vanha-liikennemerkkiquotvquot.

Suomen ympäristökeskus. 2017. "Pohjaveden havaintopaikat." https://www.syke.fi/fi-Fl/Tutkimus__kehittaminen/Vesi/Mallit_ja_tyokalut/Pohjaveden_naytteenotto/Pohjaveden_havaintopaikat(41635).

Uusi Lahti 5.12.2019. "Menikö Moskovan ja Washingtonin välinen kuuma linja myös Lahden kautta?" https:// www.uusilahti.fi/paikalliset/803533.

Verainen, Liisa-Maija. 2014. "Put ny sin palokaivo viel". Mynämäen seudun kotiseutuyhdistys. http://www. wirmo-seura.fi/index.php?id=put_ny_sin_palokaivo_viel.

Wikipedia: Palokaivo. 2019. Linkki alkuperäiseen artikkeliversioon https://fi.wikipedia.org/w/index.php?title= Palokaivo\&oldid $=18322007$.

Wikipedia. 2020. Käyttäjän Urjanhai keskustelusivu. https://fi.wikipedia.org/w/index.php?title=Keskustelu_ käyttäjästä:Urjanhai\&oldid=18849930\#Palokaivo.

Yksivaihde.net. 2008. "Moni meistä on rikollinen - jarruttomuuskeskustelu". http://www.yksivaihde.net/site/ foorumi/topic.php?id=212

Yle Uutiset 12.5.2009. "Jarruttoman fiksipyörän suosio kasvussa." https://yle.fi/uutiset/3-5250169

Yle Uutiset. 15.7.2010. "Pelastuslaitos löytää vesipostit helposti." https://yle.fi/uutiset/3-5596787.

Yle Uutiset. 10.12.2019. "Pieni vaja itärajan pinnassa on jotain aivan muuta miltä näyttää - pääsimme käymään bunkkerissa, joka on yhä täynnä kylmän sodan aikaisia viestintävälineitä." https://yle.fi/uutiset/3-11105133.

\section{Kirjallisuus}

Asetus sammutusvedenottopaikkojen merkitsemisestä 984/1943.

Haiko, Markku. 2014. Selvitys alueellisen pelastustoimen synnystä. Pelastuslaitosten kumppanuusverkoston julkaisu 3/2014. https://pelastustieto.fi/wp-content/uploads/2015/08/pelastustoimensynty.pdf.

Hyttinen, Veli, Pertti Tolonen ja Timo Väisänen. 2018. Palofysiikka. Suomen Pelastusalan Keskusjärjestö. 9. uusittu painos.

Juuti, Petri ja Riikka Rajala. 2007. Veden vuosisata. Espoon vesihuolto 1930-luvulta 2000-luvulle. Luku 3: Palokaivoja, porausta, ja ensimmäinen pumppaamo. Tampere: Tampere University Press. http://urn.fi/ urn:isbn:978-951-44-6916-9.

Kertomus Helsingin kaupungin kunnallishallinnosta vuonna 1933. Luku X. Palolaitos. https://www.hel.fi/static/ tieke/digitoidut_asiakirjat/helsingin_kunnalliskertomukset/pdf/1933/1933_32.pdf.

Linja-aho, Vesa. 2017. Kommentti: Painevalvontaa käytettiin yleisesti telekaapeleissa - ei vain kuumassa linjassa. Tekniikan Waiheita, 35(3), 77-78. https://journal.fi/tekniikanwaiheita/article/view/82341.

Paloasetus 359/1961.

Palolaki 202/1933.

Palolaki 465/1960.

Palosääntö 359/1933.

Pelastuslaki 379/2011.

Pohjakallio, Kari. 2006. 70 vuotta mäellä : Pitkäjärven vapaaehtoinen palokunta 1936-2006. Espoo: Pitkäjärven VPK.

Sihvonen, Lilli. 2019. "Aikansa mediateknologiasta kuriositeetiksi: Lankapuhelimen historiasta nykytilanteeseen ja muuttuviin merkityksiin." Tekniikan Waiheita, 37(3), 31-42. https://doi.org/10.33355/tw.86773.

Sisäasiainministeriön päätös sammutusvedenottopaikkojen merkitsemisestä 1031/1943.

Sisäasiainministeriön päätös vedenottopaikkojen merkitsemisestä 212/1964.

Kaikki verkkoviitteet tarkistettu 30.4.2020. 


\section{Muu aineisto}

Tarja Gustafsson 17.4.2020 (sähköposti artikkelin kirjoittajalle).

HSY:n asiakaspalvelun "Linda" 16.4.2020 (sähköposti artikkelin kirjoittajalle).

HSY:n asiakaspalvelun "Linda" 17.4.2020 (sähköposti artikkelin kirjoittajalle).

Kimmo Härö 16.4.2020 (sähköposti artikkelin kirjoittajalle).

Tero Kähkönen 16.4.2020 (sähköposti artikkelin kirjoittajalle).

Tiia Laukkanen 16.4.2020 (sähköposti artikkelin kirjoittajalle).

Jani Rämänen 15.4.2020 (sähköposti artikkelin kirjoittajalle).

Timo Väisänen 27.4.2020 (sähköposti artikkelin kirjoittajalle). 